\section{Tillage and Fertilizer Placement Effects on Staked Tomatoes Were Inconsistent}

\author{
Jim E. Wyatt, ${ }^{1}$ Don D. Tyler, ${ }^{2}$ \\ Craig H. Canaday, ${ }^{3}$ and \\ Don D. Howard ${ }^{4}$
}

\begin{abstract}
Additional index wORDs. Lycopersicon esculentum, no tillage, strip tillage, conventional tillage, potassium nitrate, fertilizer injection, soil conservation
\end{abstract}

Summary. This study compared conventional tillage (CT), strip tillage (ST), and no tillage (NT) cultures for effects on tomato (Lycopersicon esculentum) fruit production. Within each tillage system, fertilization treatments were $60 \mathrm{lb} /$ acre $(67.2$ $\mathrm{kg} \cdot \mathrm{ha}^{-1}$ ) of nitrogen $(\mathrm{N})$ applied as potassium nitrate in four ways: a 2 -ftwide $(0.6 \mathrm{~m})$ strip over the row before transplanting, a 4-ft-wide (1.2-m) strip over the row before transplanting, $\mathrm{N}$ banded 6 inches $(0.15 \mathrm{~m})$ to the side and 4 inches $(0.10 \mathrm{~m})$ below the plant after transplanting, or applied through the drip irrigation system. A treatment of no fertilizer was included in the 1996 study but was discontinued in 1998 and 1999 because yields were low and this would not be a recommended practice

This research was supported in part by a grant from the Natural Resources Conservation Service, United States Department of Agriculture, Soil Quality Institute, Auburn, AL. The cost of publishing this paper was defrayed in part by payment of page charges. Under postal regulations, this paper therefore must be hereby marked as advertisement solely to indicate this fact.

${ }^{1}$ Associate professor and corresponding author (jwyatt6@utk.edu), Department of Plant and Soil Sciences, The University of Tennessee, West Tennessee Experiment Station, 605 Airways Blvd., Jackson, TN 38301 .

${ }^{2}$ Professor, Department of Plant and Soil Sciences, The University of Tennessee, West Tennessee Experiment Station, 605 Airways Blvd., Jackson, TN 38301.

${ }^{3}$ Associate professor, Department of Entomology and Plant Pathology, The University of Tennessee, West Tennessee Experiment Station, 605 Airways Blvd., Jackson, TN 38301.

${ }^{4}$ Professor, Department of Plant and Soil Sciences, The University of Tennessee, West Tennessee Experiment Station, 605 Airways Blvd., Jackson, TN 38301. in Tennessee. Tillage treatments had no effect on early small, medium, or large tomato yields. In 2 of the 3 years, either ST or CT treatments resulted in the highest total yields. Highest early yields were often produced by applying $\mathrm{N}$ in either $2-\mathrm{ft}$ or 4-ft, strips over the row before transplanting. Highest late-season yields were obtained from plants receiving $\mathrm{N}$ applied as a band beside the row after transplanting. Results suggest that tomato yield under minimal tillage (ST or NT) was at least equivalent to $\mathrm{CT}$ in most years. When the economic benefits of minimal tillage are considered, these results imply that minimal tillage cultural practices are advantageous in tomato production.

$\mathrm{U}$ pland silt loam soils of the central United States in which tomatoes are conventionally planted or transplanted usually are prepared by cultivating with a moldboard or chisel plow, followed by disking and harrowing to pulverize large clods and smooth the soil surface. These preparative measures result in a loose, usually weed free, soil environment. Staked tomatoes are often grown on land with moderate to excessive slope and on some of the most easily eroded soils, especially in the southeastern U.S. (Langdale et al., 1985). Organic mulch from a cover crop will protect the soil surface from the dislodging impact of raindrops, increase the infiltration rate of water into the soil, slow the runoff of surface water, and prevent large amounts of sediment from moving into streams. Most tomato production areas could potentially benefit if NT production techniques could be adopted to minimize soil erosion (Coolman and Hoyt, 1993).

Fields planted in a NT cultural system can be entered sooner following rainfall to conduct operations necessary for proper and timely care of the crop (Tyler et al., 1994). In the case of tomatoes, this might be tying the plants, harvesting fruit, or spraying the plants with pesticides. A firm soil surface will allow heavy equipment to enter the field sooner without rutting the soil, disrupting the soil structure, intercepting the normal drainage system of the field, or disturbing the root system of large tomato plants. In addition to reducing erosion, cover crops or mulches in a NT culture can im- prove crop yields through modifying soil temperatures during the summer season (Horton et al., 1994), reducing evaporation from the soil surface (Steiner, 1994), reducing soil bulk density (Kladivko, 1994), protecting surface soil structure (Langdale et al., 1991; Unger, 1994), forming biopores (Cochran et al., 1994), controlling some weed species (Phatak etal., 1991), and releasing nutrients (Lal et al., 1991). Other benefits of NT culture include reduction in harmful insect population densities and capacity to locate host plants (Hunt, 1998; Riechert and Bishop, 1990; Zehnder and Linduska, 1987), an increase in numbers of beneficial insects (Brust, 1994; McPherson et al., 1982; Mwaja et al., 1996; Ruberson et al., 1995), less leaf necrosis in NT culture (AbdulBaki et al., 1996), and suppression of weeds (Masiunas et al., 1995). Negative aspects of cover crops or mulches include decreasing crop yields by competing for available nutrients (Lal et al., 1991), stimulating soilborne pathogens (Watkins and Boosalis, 1994), lowering soil temperatures in early spring (Horton et al., 1994), and producing phytotoxic compounds (Putnam, 1994).

Cover crops used in most tomato tillage studies have been hairy vetch (Vicia villosa) (Teasdale and AbdulBaki, 1997), subterranean clover (Trifolium subterraneum) (Abdul-Baki and Teasdale, 1993), winter rye (Secale cereale) (Drost and Price, 199la, 1991b; Masiunas et al., 1995), or wheat (Triticum aestivum) (Shelby et al., 1988; Wyatt et al., 1999). Most of this research has involved transplanting tomatoes directly into the cover crops; little information in available regarding transplanting into a strip of cultivated soil within an organic cover crop. Yields of reduced tillage tomatoes exceeded (Hunt, 1998) equaled (Masiunas et al., 1995) or were less than (Drost and Price, 1991b) conventional cultural methods. Some studies (Mwaja et al., 1996; Shelby et al., 1988 ) reported mixed results in tomato yields for tillage treatments from year to year.

Higher tomato yields resulted from banded placement of $\mathrm{N}$, phosphorus $(\mathrm{P})$, and potassium $(\mathrm{K})$ than when the same fertilizer rates were broadcast (Mortley et al., 1991) and equivalent yields were produced when two times the rate was broadcast. Leaf 
and plant nutrient contents were higher with banded treatments compared to broadcasting. Cook and Sanders (1990) found no differences in tomato yield or $\mathrm{N}$ uptake between banded and broadcast placement of $\mathrm{N}$ under black plastic mulch. Hoyt (1992) found that tomato yields increased with increasing $\mathrm{N}$ rates in winter rye or hairy vetch residues or in bare soil. He also suggested (Hoyt et al., 1994) that banded applications of $\mathrm{N}$ are more efficient than broadcast applications in no tillage culture and that urea-based fertilizers should be banded to reduce $\mathrm{N}$ losses.

Our objectives were to identify tillage systems and $\mathrm{N}$ fertilizer placement methods for staked tomatoes which will result in yields equal to or better than those with CT methods.

\section{Materials and methods}

Methods of $\mathrm{N}$ fertilizer application in staked tomatoes were studied in CT, ST, and NT growing systems in 1996, 1998, and 1999, at the West Tennessee Experiment Station, Jackson, Tenn. The test was conducted each year on a Lexington silt loam soil (Typic Paleudalf). Treatments were arranged as a split-plot experiment using a randomized complete-block design with four replications. Main plots consisted of tillage treatments and subplots were comprised of fertilizer placement treatments. Individual plots were single rows $20 \mathrm{ft}(6.1 \mathrm{~m})$ long with 10 plants spaced $2 \mathrm{ft}(0.6 \mathrm{~m})$ apart within rows. Rows were spaced $10 \mathrm{ft}(3 \mathrm{~m})$ apart to accommodate available spraying equipment. A border row was included on each side of the planting. Plots were planted in the same field each year where wheat had been drilled at $60 \mathrm{lb} /$ acre $\left(67.2 \mathrm{~kg} \cdot \mathrm{ha}^{-1}\right)$ in September of the previous year and killed with glyphosate herbicide at $16 \mathrm{fl} \mathrm{oz} /$ acre (1.17 L $\cdot \mathrm{ha}^{-1}$ ) about 2 weeks before tomato transplanting. ST plots were prepared by tilling a strip about 20 inches $(0.5 \mathrm{~m})$ wide and 4 to 6 inches $(0.10$ to $0.15 \mathrm{~m})$ deep with a rear-tine tiller. NT plots received no cultivation other than opening and then closing a furrow with a mechanical transplanter shoe (Mechanical Transplanter Co., Holland, Mich.). CT plots were prepared by disking followed by smoothing the soil with a 'Triple- $K$ ', a springtooth harrow with a rolling basket attachment in the rear (Kongskilde, Soro, Denmark). Tillage treatments in
1996 consisted of ST and NT; a CT treatment was included in the study in 1998 and 1999.

Soil test results each year indicated a high [ 161 to $320 \mathrm{lb} /$ acre ( 180 to $\left.\left.358 \mathrm{~kg} \cdot \mathrm{ha}^{-1}\right)\right]$ or very high [ $>320$ $\mathrm{lb} /$ acre $\left.\left(358 \mathrm{~kg} \cdot \mathrm{ha}^{-1}\right)\right]$ level of available K in the plots using the Mehlich I extraction method. Phosphorus was also in the very high $[>120 \mathrm{lb} /$ acre $\left.\left(134 \mathrm{~kg} \cdot \mathrm{ha}^{-1}\right)\right]$ range. Therefore, no additional $\mathrm{P}$ and only the $\mathrm{K}$ from potassium nitrate $\left(\mathrm{KNO}_{3}\right)$ was applied.

Fertilization placement treatments each year were $60 \mathrm{lb} /$ acre $\left(67.2 \mathrm{~kg} \cdot \mathrm{ha}^{-1}\right)$ of $\mathrm{N}$ from $\mathrm{KNO}_{3}$ applied 1 ) in a 2 - $\mathrm{ft}$ strip over the row before transplanting, 2) applied in a 4$\mathrm{ft}$ strip over the row before transplanting, 3) banded 6 inches to the side and 4 inches below the soil surface after transplanting, and 4) applied through the drip irrigation system at 10,20 , and $30 \mathrm{lb} /$ acre $\left(11.2,22.4\right.$, and $33.6 \mathrm{~kg} \cdot \mathrm{ha}^{-}$ $\left.{ }^{1}\right)$ applied at 2, 4, and 6 weeks after transplanting, respectively. A fertility treatment with no fertilizer wasincluded in the 1996 study only. In addition to the treatment fertilizers, two sidedressings of $30 \mathrm{lb} /$ acre of $\mathrm{N}$ derived from calcium nitrate were applied to all tomatoes as a banded application, one about 4 weeks after transplanting when first fruit were about 0.8 inch $(2 \mathrm{~cm})$ in diameter, and another 3 weeks later.

The entire experiment was irrigated with a drip irrigation system each year. An additional irrigation line was placed in plots which received $\mathrm{N}$ through the irrigation system and appropriate amounts of $\mathrm{KNO}_{3}$ were applied in about $1 \mathrm{gal}(3.7 \mathrm{~L})$ of solution per plot at each treatment period. The system was then flushed with about 1 gal of water per plot. Rainfall was supplemented with drip irrigation to provide about $l$ inch $(2.5 \mathrm{~cm})$ of water per week during fruit development.

'Mountain Delight' tomatoes were seeded in a greenhouse on 13 Mar. and transplanted into field plots on 17 Apr. 1996. 'Mountain Fresh'

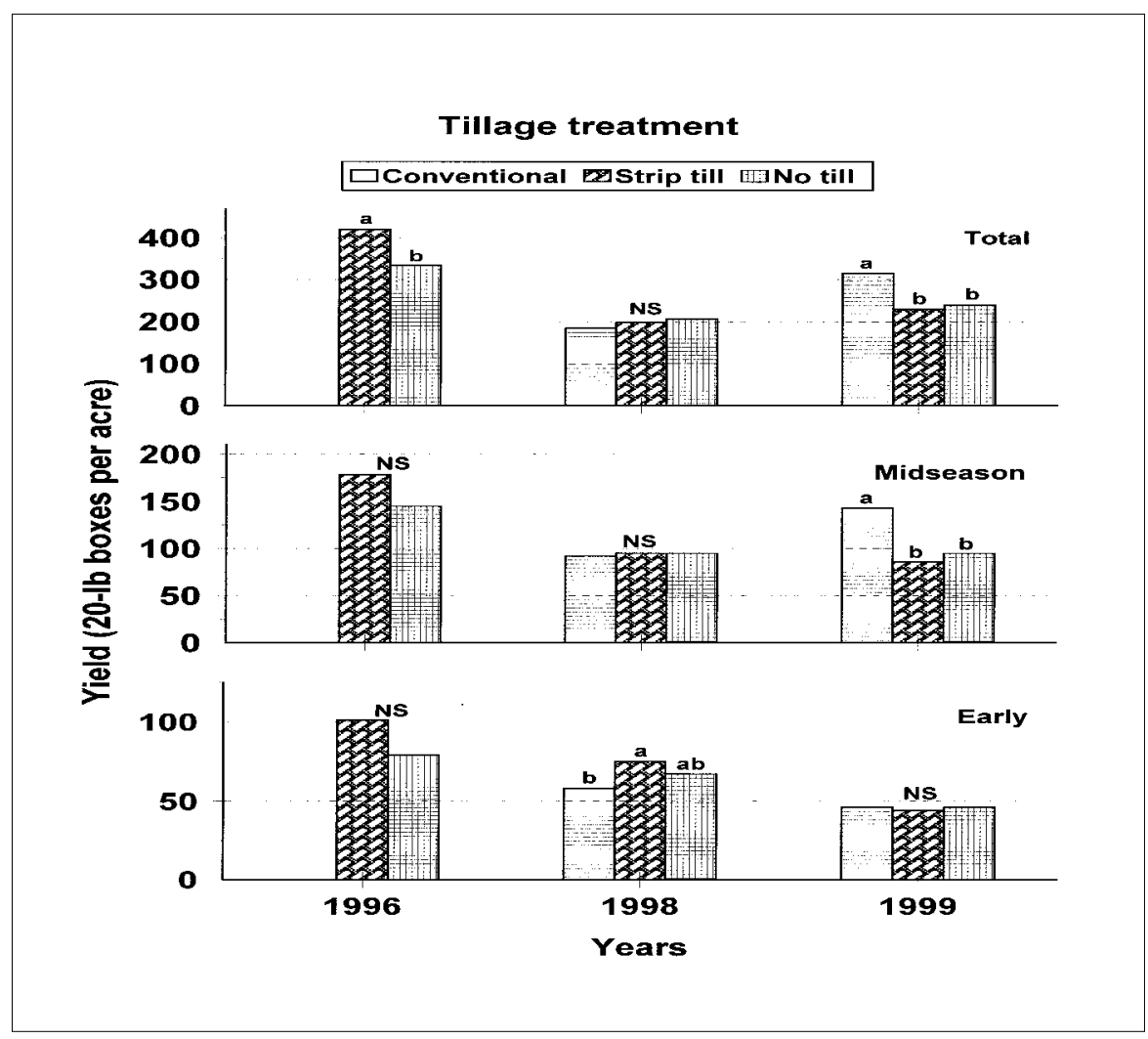

Fig. 1. Effects of tillage treatments on early, midseason, and total yield of extra large tomatoes [ $>228 / 32$ inches $(>73 \mathrm{~mm})$ in diameter] for 3 years. Harvest periods: early (1996 = 24 June through 5 July; 1998 = 25 June through 10 July; 1999 = 27 June through 6 July); midseason (1996 = 9 July through 22 July; 1998 = 13 July through 20 July; 1999 = 9 July through 15 July); total (1996 = 24 June through 29 July; 1998 = 25 June through 3 Aug.; 1999 = 27 June through $23 \mathrm{July}$ ). A $20-1 \mathrm{~b}$ box $=9.1 \mathrm{~kg}$. Bars within each harvest period with the same letter are not significantly different by LSD, $P=0.05$. 
tomatoes were seeded in a greenhouse on 12 and 16 Mar. 1998 and 1999, respectively, and transplanted into field plots on 24 and 22 Apr 1998 and 1999, respectively. Recommended cultural practices for staked tomatoes in western Tennessee (Rutledge et al., 1993) were followed for weed, disease, and insect control. Plants were staked and supported using the Florida weave tying system in which a stake is placed between every other plant and a nylon string is tied between stakes to support the tomato plants from both sides (Rutledge et al., 1993). Fruit were harvested at mature-green or breaker stage of maturity. Fruit were counted and graded (USDA, 1976) into small [ $24 / 32$ to $29 / 32$ inches (54 to $58 \mathrm{~mm}$ ) in diameter], medium [29/ 32 to $217 / 32$ inches ( 58 to $64 \mathrm{~mm}$ ) in diameter], large [ $217 / 32$ to $228 / 32$ inches $(64$ to $73 \mathrm{~mm})$ in diameter], and extra large [ $>2$ 28/32 inches (73 $\mathrm{mm}$ ) in diameter] sizes. Harvests were arbitrarily broken into early (24 June through 5 July, 1996; 25 June through 10 July, 1998; 27 June through 6 July, 1999), midseason (9 July through 22 July, 1996; 13 July through 20 July, 1998; 9 July through 15 July, 1999), and late (22 July through 29 July, 1996; 24 July through 3 Aug., 1998; 19 July through 23 July, 1999) harvest periods.

Data were converted to per-acre yields and subjected to analysis of variance (ANOVA) using appropriate SAS procedures (SAS Institute Inc., Cary, N.C.). Means were separated using least significant differences (LSD) at $P$ 0.05 where applicable.

\section{Results and discussion}

No interactions were found between tillage and fertilizer placement treatments for effects on yield. Although a wide row spacing was used in this study, the fruit yield per plant was typical of that expected in Tennessee. Few tillage treatments resulted in significant differences in tomato yields by size or harvest period and most tillage data are not presented. Since extra large fruit are usually the highest valued of a spring-grown tomato crop, data are presented for extra large yields (Fig. 1). In 1996, total yields of extra large tomatoes with ST were significantly higher than with NT (Fig. 1). In 1998, yields of early extra large tomatoes with ST were significantly higher than early extra large tomatoes with
CT, but not different from early tomatoes with NT. In 1999, midseason and total yields of extra large tomatoes with CT were significantly higher than yields with either ST or NT. Significant differences between and among tillage treatments for total yields of all size grades of tomatoes were similar to those of extra large tomatoes (Fig. 2).

These inconsistent results have been documented by others in tomato tillage studies (Mwaja et al., 1996; Shelby et al., 1988). Year-to-year differences in plant productivity between treatments may be due to changes in physical and nutritional soil characteristics resulting from breakdown of cover crop residues or increased numbers of disease organisms in soils (Dabney et al., 1996; Rothrock et al., 1994) or other factors, such as differences in soil temperature (Horton et al., 1994) or soil moisture (Steiner, 1994).

Early total fruit production, usually the most profitable in spring-grown tomatoes, was largely unaffected by tillage (Fig. 2). Where treatment effects on early total yields were significant in 1998, yield with ST was higher than with CT. Early tomato yield under minimal tillage (ST or NT) was at least equivalent to CT in the two seasons where all three treatments were used in the experiment. These findings are similar to those of Masiunas et al. (1995) and Drost and Price (1991b), who found yields with NT were no different from CT when tomatoes were grown in killed rye or wheat. When the previously mentioned benefits of minimal tillage are considered, these yield results imply that minimal tillage cultural practices are sometimes advantageous in production of early-season tomatoes. However, minimal tillage treatments resulted in lower, or equal total-season yields than CT in the two seasons where all three treatments were used in the experiment.

Application of no fertilizer in 1996 resulted in lower early large, early extra large, and early total tomato yields

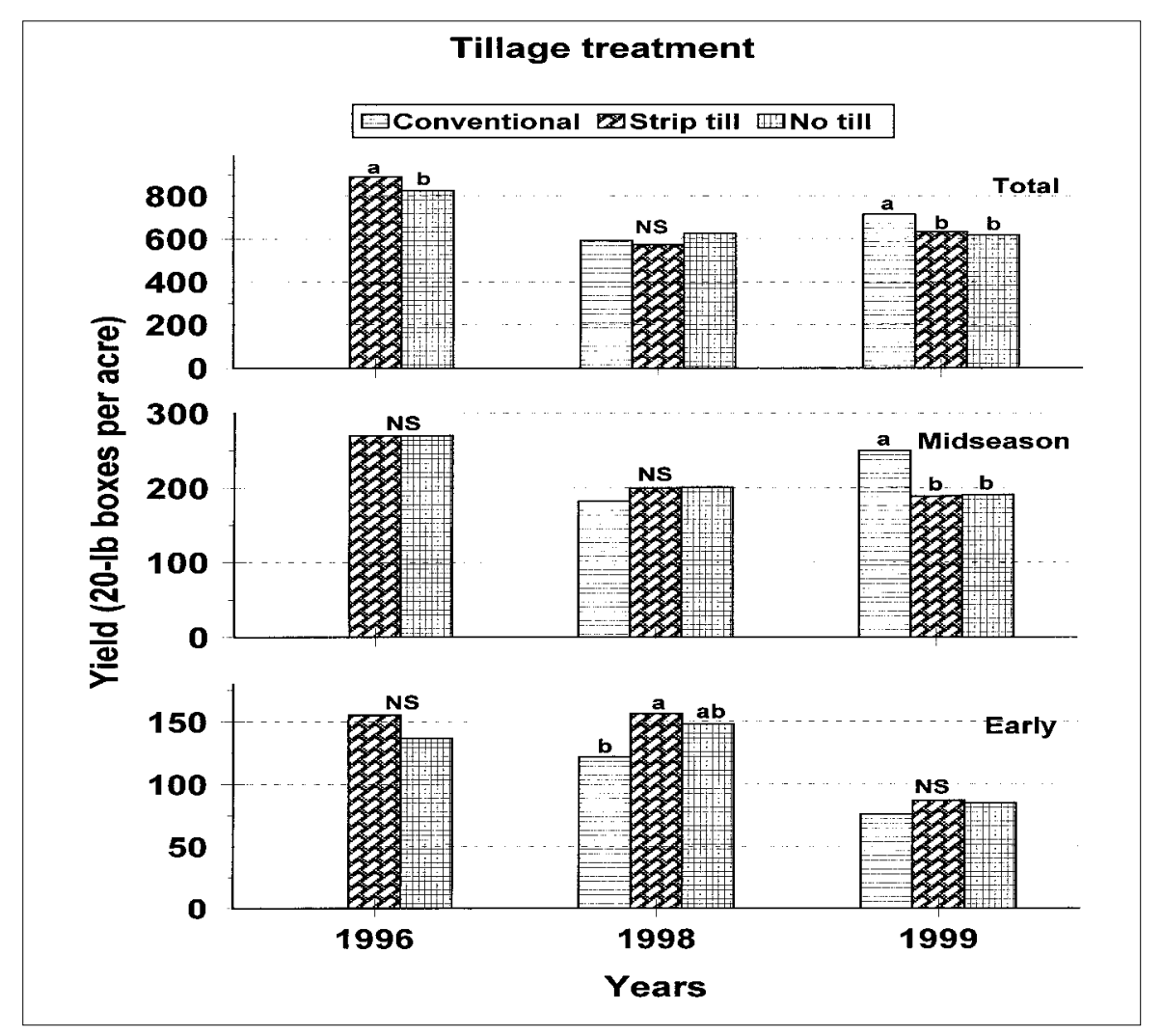

Fig. 2. Effects of tillage treatments on early, midseason, and total yield of all marketable tomatoes for 3 years. Harvest periods: early (1996 = 24 June through 5 July; 1998 = 25 June through 10 July; $1999=27$ June through 6 July); midseason (1996 = 9 July through 22 July; 1998 = 13 July through 20 July; 1999 = 9 July through 15 July); total (1996 = 24 June through 29 July; 1998 = 25 June through 3 Aug.; 1999 = 27 June through 23 July). A 20-1b box $=9.1 \mathrm{~kg}$. Bars within each harvest period with the same letter are not significantly different by LSD, $P=0.05$. 


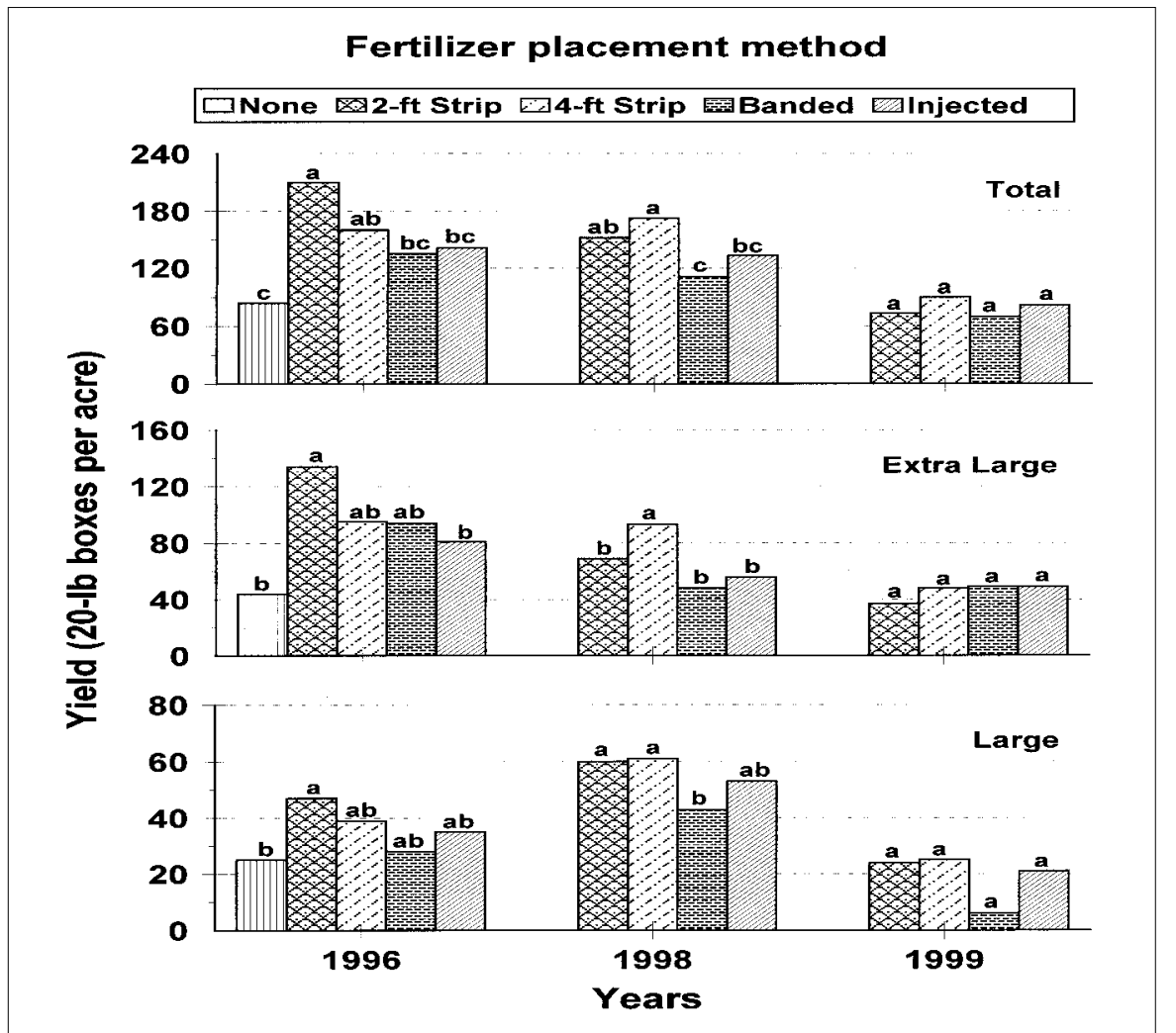

1999 for early large, early extra large, or early total tomato yields.

In general, large, extra large, and total tomato yields were higher with the banded and injected fertilizer placement treatments than with the stripapplied treatments during the late part of the harvest season (Fig. 4). In 1996, the banded treatment resulted in higher late large, extra large, and total yields than the 2-ft strip treatment, and higher late large and extra large yields than the 4 -ft strip treatment. The injected treatment also resulted in higher late extra large and total yields than with the 2-ft strip treatment in 1996. In 1998 , the banded treatment resulted in higher late large and total yields than with the 4 -ft strip treatment and higher late total yields than with the 2$\mathrm{ft}$ strip treatment. In 1999, total yields of late tomatoes were higher with the banded treatment than with the $4-\mathrm{ft}$ strip treatment.

Total yields of all tomatoes are presented in Fig. 5. This includes the midseason portion of the harvest in

Fig. 3. Effects of fertilizer placement methods on early large, early extra large, and total early yield of marketable tomatoes for 3 years. Early harvest periods: $(1996=24$ June through 5 July; 1998 = 25 June through $10 \mathrm{July;} 1999=27$ June through 6 July). Large tomatoes $=2$ $17 / 32$ to $228 / 32$ inches $(64$ to $73 \mathrm{~mm}$ ) in diameter; extra large tomatoes $=>2$ $28 / 32$ inches $(>73 \mathrm{~mm})$ in diameter. $A$ $20-1 b$ box $=9.1 \mathrm{~kg}$. Bars within each harvest period with the same letter are not significantly different by LSD, $P=$ $0.05 ; 1 \mathrm{ft}=0.3 \mathrm{~m}$.

than yield with the 2 -ft strip, and lower early total yields than with the 4 -ft strips (Fig. 3). For these reasons, this treatment was discontinued in 1998 and 1999. Early total yields were also higher with the 4 -ft strip than with either banded or injected treatments. In 1998, the 4-ft strip treatment resulted in significantly higher yields of early large tomatoes than the banded treatment, higher yields of early extra large tomatoes than with the 2 -ft strip, the banded, or the injected treatments, and higher early total yields than the banded or injected treatments. In addition, the 2 -ft strip treatment resulted in higher early total yields than the banded treatment in 1998. No differences among treatments were found in

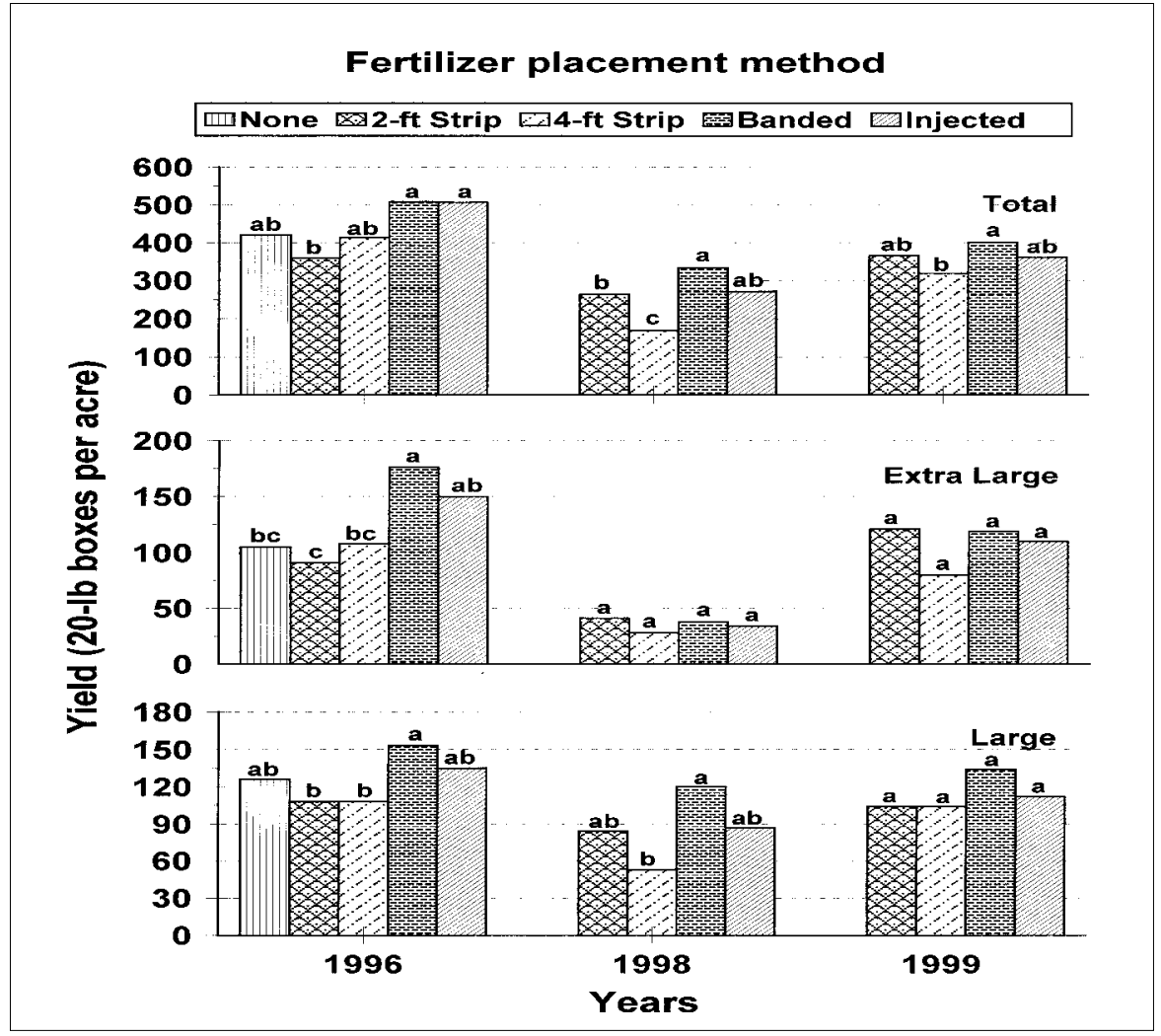

Fig. 4. Effects of fertilizer placement methods on late large, late extra large, and total late yield of marketable tomatoes for 3 years. Late harvest periods: ( 1996 = 22 July through 29 July; 1998 = 24 July through 3 Aug.; $1999=19$ July through 23 July). Large tomatoes = $217 / 32$ to $228 / 32$ inches (64 to 73 $\mathrm{mm})$ in diameter; extra large tomatoes $=>228 / 32$ inches $(>73 \mathrm{~mm})$ in diameter. A 20-1b box $=9.1 \mathrm{~kg}$. Bars within each harvest period with the same letter are not significantly different by $L S D, P=0.05 ; 1 \mathrm{ft}=0.3 \mathrm{~m}$. 


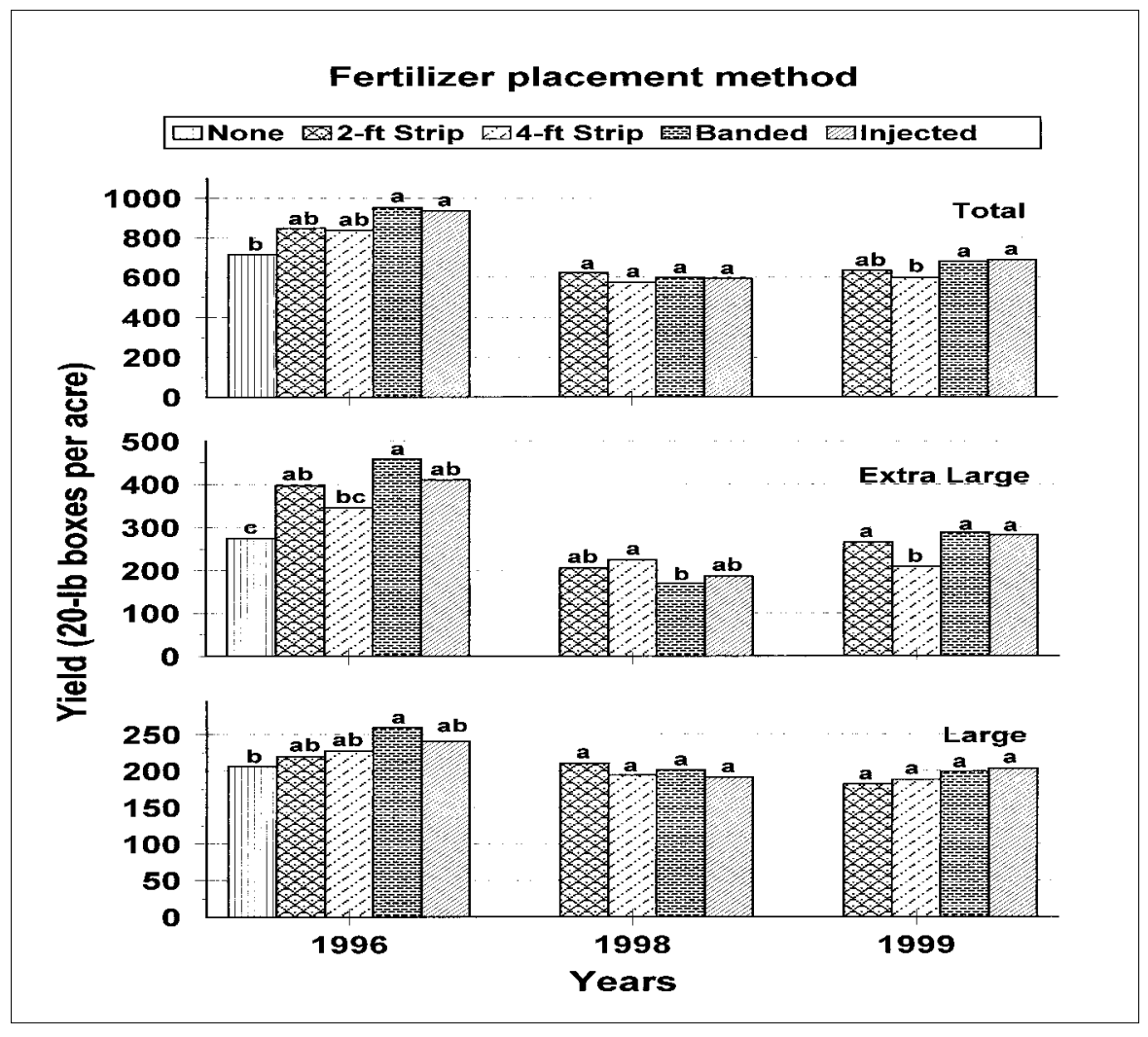

Fig. 5. Effects of fertilizer placement methods on total large, total extra large, and total yield of marketable tomatoes for 3 years. Large tomatoes $=2$ 17/32 to $228 / 32$ inches $(64$ to $73 \mathrm{~mm}$ ) in diameter; extra large tomatoes $=>228 / 32$ inches $(>73 \mathrm{~mm})$ in diameter. A $20-1 \mathrm{~b}$ box $=9.1 \mathrm{~kg}$. Bars within each harvest period with the same letter are not significantly different by $L S D, P=0.05$; $1 \mathrm{ft}$ $=0.3 \mathrm{~m}$.

addition to the early and late segments presented in Figs. 3 and 4. Yields with the banded placement treatment were higher for total large, extra large, and total harvested tomatoes than with the unfertilized control in 1996. The injected treatment also resulted in higher yields of total extra large and total harvested tomatoes than with the unfertilized control, and greater yields of total extra large tomatoes than with the 4-ft strip in 1996. In 1998, extra large yields were higher with the 4 -ft strip treatment than with the banded treatment. In 1999 the 4 -ft strip treatment resulted in less yield than all other treatments for total extra large tomatoes and less than the banded and injected treatments for total tomatoes harvested.

Since neither of the strip-applied fertilizer treatments was significantly different from the unfertilized control for total large tomatoes or total season harvest in 1996 (Fig. 5), it might be concluded that these placement methods would not be viable alternatives to banded placement for tomato production. Mortley et al. (1991) concluded because of excessive rainfall or some of the $\mathrm{N}$ may have been lost to leaching after $\mathrm{N}$ injection.

Tomato yields from minimal tillage treatments (ST or NT) were equivalent to yields from CT in most years. Benefits of reduced tillage must be considered when growers make management decisions regarding how tomatoes will be produced. Our data on total tomato yield suggest that banded or injected fertilizer placement might be the most effective for tomatoes under reduced tillage conditions.

\section{Literature cited}

Abdul-Baki, A.A. and J.R. Teasdale. 1993. A no-tillage tomato production system using hairy vetch and subterranean clover mulches. HortScience 28(2):106-108.

Abdul-Baki, A.A., A.E. Watada, J.R. Teasdale, and R.D. Morse. 1996. Hairy vetch mulch favorably impacts yield of processing tomatoes. HortScience 31(3):338-340.

Brust, G.E. 1994. Natural enemies in straw mulch reduce Colorado potato beetle populations and damage in potato. Biol. Control 4:163-169.

Cochran, V.L., S.D. Sparrow, and E.B. Sparrow. 1994. Residue effects on soil micro- and macroorganisms, p. 163-184. In: P.W. Unger (ed.). Managing agricultural residues. Lewis Publishers, Boca Raton, Fla.

Cook, W.P. and D.C. Sanders. 1990. Fertilizer placement effects on soil nitrogen and use by drip-irrigated and plasticmulched tomatoes. HortScience 25(7):767-769.

Coolman, R.M. and G.D. Hoyt. 1993. The effects of reduced tillage on the soil environment. Hort Technology 3:143-145.

Dabney, S.M., J.D. Schreiber, C.S. Rothrock, and J.R. Johnson. 1996. Cover crops affect sorghum seedling growth. Agron. J. 88(6):961-970.

Drost, D.T. and H.C. Price. 1991a. Stand establishment of fluid-drilled tomato in rye and wheat tillage systems. HortScience 26(12):1475-1478.

Drost, D.T. and H.C. Price. 1991b. Effect of tillage system and planting date on the growth and yield of transplanted tomato. HortScience 26(12):1478-1480.

Horton, R., G.J. Kluitenberg, and K.L. Bristow. 1994. Surface crop residue effects on the soil surface energy balance, p. 143162. In: P.W. Unger (ed.). Managing agricultural residues. Lewis Publishers, Boca Raton, Fla. 
Hoyt, G.D. 1992. Effect of cover crop and $\mathrm{N}$ rate on soil $\mathrm{N}$ and yield of no-till sweet corn and strip-till tomato. HortScience 27(6):663 (abstr.).

Hoyt, G.D., D.W. Monks, and T.J. Monaco. 1994. Conservation tillage for vegetable production. HortTechnology 4:129-135.

Hunt, D.W.A. 1998. Reduced tillage practices for managing the Colorado potato beetle in processing tomato production. HortScience 33(2):279-282.

Kladivko, E.J. 1994. Residue effects on soil physical properties, p. 123-141. In: P.W. Unger (ed.). Managing agricultural residues. Lewis Publishers, Boca Raton, Fla.

Lal, R., E. Regnier, D.J. Eckert, W.M. Edwards, and R. Hammond. 1991. Expectations of cover crops for sustainable agriculture, p. 1-11. In: W.L. Hargrove (ed.). Proc. Cover Crops for Clean Water.

Langdale, G.W., H.P. Denton, A.W. White, J.W. Gilliam, and W.W. Frye. 1985. Effects of soil erosion on crop productivity of southern soils, p. 251-271. In: R.J. Follet and B.A. Stewart (eds.). Soil erosion and crop productivity, Amer. Soc. Agron., Madison, Wis.

Langdale, G.W., R.L. Blevins, D.L. Karlen, D.K. McCool, M.A. Nearing, E.L. Skidmore, A.W. Thomas, D.D. Tyler, and J.R. Williams. 1991. Cover crop effects on soil erosion by wind and water, p. 15-22. In:W.L. Hargrove (ed.). Proc. Cover Crops for Clean Water.

Mwaja, V.N., J.B. Masiunas, and C.E. Eastman. 1996. Rye (Secale cereale L.) and hairy vetch (Vicia villosa Roth) intercrop management in fresh-market vegetables. J. Amer. Soc. Hort. Sci. 121(3):586-591.

Masiunas, J.B., L.A. Weston, and S.C. Weller. 1995. The impact of rye crops on weed populations in a tomato cropping system. Weed Sci. 43(2):318-323.

McPherson, R.M., J.C. Smith, and W.A. Allen. 1982. Incidence of arthropod predators in different soybean cropping systems. Environ. Entomol. 11:685-689.

Mortley, D.G., C.B. Smith, and K.T. Demchak. 1991. Fertilizer placement affects growth, fruit yield, and elemental concentrations and contents of tomato plants. J. Amer. Soc. Hort. Sci. 116(4):659662.

Phatak, S.C., R.L. Bugg, D.R. Sumner, J.D. Gay, K.E. Brunson, and R.B. Chalfant. 1991. Cover crop effects on weeds, diseases, and insects of vegetables, p. 153154. In: W.L. Hargrove (ed.). Proc. Cover Crops for Clean Water.

Putnam, A.R. 1994. Phytotoxicity of plant residues, p. 285-314. In: P.W. Unger(ed.). Managing agricultural residues. Lewis Publishers, Boca Raton, Fla.

Reichert, S.E. and L. Bishop. 1990. Prey control by an assemblage of generalist predators: Spiders in a garden test system. Ecology 71:1441-1450.

Rothrock, C.S., J.D. Mueller, M.J.Sullivan, P.M. Porter, J.S. McConnell, T.L. Kirkpatrick, T.C. Keisling, L.D. Parsch, and P.D. Colyer. 1994. Use of legume winter cover crops in cotton production systems. Proc. 1994 Southern Conservation Tillage Conf. for Sustainable Agr. p. 188-193.

Ruberson, J.R., W.J. Lewis, D.J. Waters, O. Stapel, and P.B. Haney. 1995. Dynamics of insect populations in a reducedtillage, crimson clover/cotton system. Part I. Pests and beneficials on plants. Proc. 1995 Beltwide Cotton Conf. p. 814-817.

Rutledge, A.D., J.B. Wills, and S. Bost. 1993. Commercial tomato production. Univ. Tenn., Knoxville, Agr. Ext. Serv. Bul. PB 737.
Shelby, Jr., P.P. D.L. Coffey, G.N. Rhodes, Jr., and L.S. Jeffery. 1988. Tomato production and weed control in no-tillage versus conventional tillage. J. Amer. Soc. Hort. Sci. 113(5):675-678.

Steiner, J.L. 1994. Crop residue effects on water conservation, p. 4l-76. In: P.W. Unger (ed.). Managing agricultural residues. Lewis Publishers, Boca Raton, Fla.

Teasdale, J.R. and A.A. Abdul-Baki. 1997. Growth analysis of tomatoes in black polyethylene and hairy vetch production systems. HortScience 32(4):659-663.

Tyler, D.D., W. Halfman, H.P. Denton, and P.W. Tracey. 1994. Trafficability and rooting depth comparisons between notill and tilled soybeans. Proc. 1994 Southern Conservation Tillage Conf. for Sustainable Agr. p. 137-143.

Unger, P.W. 1994. Residue managementWhat does the future hold? p. 425-432. In: P.W. Unger (ed.). Managing agricultural residues. Lewis Publishers, Boca Raton, Fla.

U.S. Department of Agriculture. 1976. United States standards for grades of fresh tomatoes. U.S. Dept. Agr., Agr. Mktg. Serv., Wash., D.C.

Watkins, J.E. and M.G. Boosalis. 1994. Plant disease incidence as influenced by conservation tillage systems, p. 261-283. In: P.W. Unger (ed.). Managing agricultural residues. Lewis Publishers, Boca Raton, Fla.

Wyatt, J.E., D.D. Howard, D.D. Tyler, and C.H. Canaday. 1999. Tillage systems and fertilization methods for staked tomatoes. HortScience 34(3):465 (abstr.).

Zehnder, G.W. and J.J. Linduska. 1987. Influence of conservation tillage practices on populations of Colorado potato beetle (Coleoptera: Chrysomelidae) in rotated and nonrotated tomato fields. Environ. Entomol. 16(1):135-139. 